\title{
Peran Orang Tua dalam Meningkatkan Kemandirian Anak Pada Kegiatan Belajar di Rumah di TK X
}

\author{
Ade Iis Kurniawati* \\ Prodi Pendidikan Guru PAUD, Fakultas Tarbiyah dan Keguruan, \\ Universitas Islam Bandung, Indonesia. \\ *adeiisk62@gmail.com
}

\begin{abstract}
This study was conducted with the aim of describing how the role of parents in increasing children's independence in learning activities at home is carried out through daily worship activities, learning activities, self help activities and parental barriers in instilling independence in children at home. The research method used is descriptive qualitative method to describe the role of parents in increasing children's independence in learning activities at home according to the condition of the child at home which is currently experiencing a pandemic. Data collection techniques in this study include interviews, observation and documentation. The results in the research that have been obtained are in the form of an overview of the way the role of parents in instilling children's independence which consists of how parents instill children's independence in daily worship activities while at home such as (prayer, recite the Koran, behave well and others), the way people parents instill children's independence in online learning activities such as (reading, writing, counting, singing and others), the way parents instill children's independence in self-help activities such as (learning to write alone, eating and drinking alone, learning to recite alone, wearing own clothes). and others) as well as obstacles for parents in instilling children's independence during learning at home such as (busy working as a housewife, busy working there is a duty as a teacher, environmental conditions and so on).
\end{abstract}

Keywords: Independence, Parents, Children, Learning Activities.

Abstrak. Penelitian ini dilakukan dengan tujuan untuk mendeskripsikan tentang cara peran orang tua dalam meningkatkan kemandirian anak pada kegiatan belajar di rumah yang dilakukan melalui kegiatan ibadah harian, kegiatan belajar, kegiatan self help serta hambatan orang tua dalam menanamkan kemandirian pada anak di rumah. Metode penelitian yang digunakan adalah metode kulitatif deskriptif untuk menggambarkan peran orang tua dalam meningkatkan kemandirian anak pada kegiatan belajar di rumah sesuai dengan kondisi anak di rumah yang pada saat ini sedang pandemin. Teknik pengumpulan data dalam penelitian ini meliputi wawancara, observasi dan dokumentasi. Hasil dalam penelitian yang telah di dapat berupa gambaran mengenai cara peran orang tua dalam menanamkan kemandirian anak yang terdiri dari cara orang tua menanamkan kemandirian anak dalam kegiatan ibadah harian selama di rumah seperti (shalat, mengaji, berperilaku baik dan lain-lain), cara orang tua menanamkan kemandirian anak dalam kegiatan belajar onlinen seperti (membaca, menulis, berhitung, bernyanyi dan lain-lain), cara orang tua menanamkan kemandirian anak dalam kegiatan self help seperti (belajar menulis sendiri, makan minum sendiri, belajar mengaji sendiri, memakai baju sendiri dan lain-lain) serta habatan bagi orang tua dalam menanamkan kemandirian anak pada masa belajar di rumah seperti (sibuk bekerja menjadi ibu rumah tangga, sibuk bekerja ada yang bertugas menjadi guru, kondisi lingkungan dan sebagainya).

Kata Kunci: Kemandirian, Orang Tua, Anak, Kegiatan Belajar. 


\section{A. Pendahuluan}

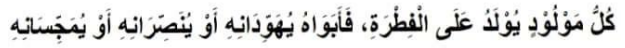

"Setiap anak dilahirkan atas fitrah (kesucian Agama yang sesuai dengan naluri), sehingga lancar lidahnya, maka kedua orang tuanyalah yang menjadikan dia beragama Yahudi, Nasrani atau Majusi." ( H.R. Abu ya"la, Thabrani dan Baihaqi) (Dr. Idrus Sere, 2018) Dari hadis diatas bahwa mendidik anak itu penting karena perkembangan dan petumbuhan anak tersebut dimulai dari sejak dini sesuai dengan fitrahnya yang dikatakan oleh sabda Rasullah Saw pada hadis diatas tersebut. Maka hal ini penting bagi peran orang tua dalam mendidik anaknya dan pendidikan anak tersebut berawal dari keluarga, keluarga merupakan tempat pertama dan utama bagi pembentukan karakter dan pendidikan anak. Ketika akan membentuk karakter anak yang baik dari segi keagamaan maupun sosial maka keluarga tersebut yang paling utamanya dalam mendidik anaknya, terutama orang tua harus memberikan pelayanan yang baik pula. Oleh karena itu faktor pentingnya peran orang tua dalam mendidik anaknya saat kondisi masa belajar di rumah ini yaitu dengan cara meningkatkan kemandirian, kemandirian anak penting ditumbuh kembangkan sejak dini. Sebab ini penting karena ada kebiasaan dilingkungan orang tua saat ini untuk memberikan perlindungan secara tidak terlalu berlebihan terhadap anaknya misalnya ketika sedang berjalan anak tersebut tiba-tiba jatuh tidak dapat berdiri. hal ini, orang tua tidak boleh langsung membantu anaknya untuk berdiri, berikan anak tersebut kesempatan untuk berdiri telebih dahulu dengan sendiri, kemudian setelah anak tersebut tidak mampu maka orang tua boleh membantu anak tersebut bediri.

Berdasarkan penjelasan latar belakang diatas, maka perumusan masalah dalam penelitian ini sebagai berikut: "Bagaimana Peran Orang Tua Dalam Meningkatkan Kemandirian Anak pada Kegiatan Belajar Di Rumah di TK PGRI Tunas Mekar ?". serta Tujuan penelitian ini adalah untuk mendapatkan informasi serta data empirik mengenai Peran Orang Tua Dalam Meningkatkan Kemandirian Anak Pada Kegiatan Belajar Di Rumah Di TK PGRI Tunas Mekar. adapun pertanyaan penelitian sebagai berikut:

1. Bagaimana cara orang tua menanamkan kemandirian anak dalam kegiatan ibadah harian selama masa belajar di rumah?

2. Bagaimana cara orang tua menanamkan kemandirian anak dalam kegiatan pembelajaran online selama masa belajar di rumah?

3. Bagaimana cara orang tua menanamkan kemandirian anak dalam kegiatan menolong diri sendiri (self help)?

4. Apa saja hambatan bagi orang tua dalam menanamkan kemandirian anak pada masa belajar di rumah?

\section{B. Metodologi Penelitian}

Metode penelitian ini menggunakan Pendekatan kualitatif merupakan metode penelitian yang kurang tersusun dikarenakan penelitian ini dilaksanakan bersama dengan langkah ikuti informasi yang ditemukan di lapangan. Kemudian, instrumen yang dibuat untuk pengambilan informasi pun bisa berubah-ubah sesuai dengan situasi lapangan. Metode ini bertujuan untuk menggambarkan atau menggambarkan ulang berkenaan momen yang berjalan terlampau sesuai bersama faktanya agar informasi yang didengar pun biasanya berwujud sebuah pemaparan informasi yang didapat dilapangan (Sugiyono, 2017).

Penelitian ini dilaksanakan di TK PGRI Tunas Mekar. Penelitian dalam subjek ini berjumlah 7 orang dari orang tua anak. Dalam pengumpulan data yang dilakukan menggunakan wawancara, observasi dan dokumentasi. Wawancara yang dilakukan dalam penelitian ini dengan cara terstruktur serta pertanyaannya tersebut sesuai dengan data yang akan diteliti. Data penelitian yang terkumpul akan di analisis dengan cara memakai langkah-langkah seperti reduksi data, penyajian data, dan verifikasi penarikan kesimpulan dalam penelitian adapun langkah-langkah penelitiannya seperti ini, pengumpulan data dengan cara membuat kisi-kisi instrumen penelitian atau pedoman penelitian, mencari referensi yang mendukung dari berbagai 
sumber. Reduksi data untuk mengelompokan hasil wawancara serta mengolah data wawancara yang didukung oleh sumber artikel. penyajian data untuk menyusun hasil pengelompokan wawancara yang didukung dengan beberapa sumber serta dinarasikan.penarikan kesimpulan dan verifikasi terkait peran orang tua dalam meningkatkan kemandirian anak dan ada teknik keabsahan yang digunakan dalam penelitian ini yaitu triangulasi (Sugiyono, 2017).

\section{Hasil Penelitian dan Pembahasan}

Kemandirian merupakan kesanggupan untuk melepaskan diri dari keadan terhadap orang lain dalam melaksanakan kegiatan atau tugas sehari-hari sendiri atau dengan sedikit bimbingan, sesuai dengan tahapan perkembangan dan kapasitasnya (Ali , Mohamad, Asrori, \& Mohamad, 2016). Menurut Behavioristik (J.B.Waston, Thorndike,Skiner, ect) dalam buku (Erhamwilda, 2018) menyatakan belajar sebagai proses perubahan pada perilaku yang tampak. Sementara para ahli kognitif (Piaget,Glaser, dkk) cenderung dapat diamati, sedangkan perubahan tingkah laku yang tampak adalah refleksi dari perubahan yang sifatnya internal. Selanjutnya para ahli yang termasuk tokoh Neo Behaviorisme (Albert Bandura) dengan teori belajar sosial menyatakan ketika seseorang belajar perubahan yang dialaminya bukanlah sekedarnya yang ditampakkan oleh tingkah lakunya, tapi jauh lebih dari itu, dan lingkungan sosial turut mempengaruhi perubahan perilaku. Epstein dalam (Diadha \& Reminur, 2015) menyatakan bahwa pembelajaran di rumah adalah kegiatan orang tua dalam membentuk anak belajar di rumah berdasarkan kegiatan yang ada di sekolah. Menurut Fadillah didalam artikel (Lilawati, 2020) mengatakan bahwa lingkungan keluarga bagi setiap anak, seluruh perilaku yang muncul pada diri anak akan tampak dari kedua orang tuanya yang memberikan model dalam mendidik kemandirian anak tersebut oleh karena itu orang tua memiliki peranan yang sangat penting bagi anaknya sendiri.

\section{Cara Orang Tua Menanamkan Kemandirian Anak Dalam Kegiatan Ibadah Harian Selama Masa Belajar Di Rumah}

Berdasarkan hasil temuan dilapangan melalui wawancara bahwa menanamkan kemandirian anak dalam ibadah harian di rumah yang dilakukan orang tua yaitu orang tua sebagai contoh yang baik bagi anak-anaknya di rumah dalam melakukan segala hal yang dapat diikuti oleh anak ketika orang tua berperilaku baik maka anak akan mengikuti orangtuanya berperilaku baik seperti ibadah harian di rumah anak harus sudah terbiasa mengenal aturan beribadah terlebih dahulu setelah itu anak bertahap melakukan ibadah harian di rumah seperti shalat lima waktu, mengaji, mengambil wudhu, berperilaku baik terhadap sesama manusia, berlatih puasa ramadhan. Adapun hasil observasi peran orang tua ketika memerintahkan anak untuk melakukan ibadah shalat di rumah orang tua belum sepenuhnya menerapkan kedisiplinan waktu dalam beribadah sholat kebanyakan orang tua mengikuti kemauan anak tanpa memberikan aturan tertentu seperti memerintahkan sholat lima waktu secara teratur dan tepat waktu masih jarang mereka lakukan, kemudian pemilihan tempat ibadah secara sendiri anak sudah mulai melakukannya kebanyakan anak perempuan mereka melakukan ibadah di rumah dan untuk anak laki - laki sesekali mereka lebih memilih ke mesjid karena mencontoh ayahnya yang suka melakukan ibadah sholat di mesjid. Selain itu, ada juga anak yang melakukan ibadah shalat dengan bimbingan orang tua. Untuk ibadah harian yang lain seperti meng aji, kebanyakan orang tua dari seluruh responden suka untuk mengajari anak mereka mengaji selain diajari langsung ada juga orang tua yang menyuruh guru ngaji khusus untuk mengajari anaknya.

Kemudian, respon anak ketika diperintahkan untuk melakukan ibadah sehari-hari selama di rumah kebanyakan dari mereka senang mengerjakannya apalagi jika ibadahnya diawasi langsung atau diperhatikan langsung oleh orang tuanya. Maka berdasarkan fakta temuan dari hasil wawancara dan observasi penelitian yang sudah disebutkan diatas hal, ini relevan dengan apa yang dikatakan oleh Fadillah didalam artikel (Lilawati, 2020) bahwa lingkungan keluarga bagi anak, seluruh perilaku yang muncul pada diri anak akan tampak dari peran orang tuanya yang memberikan model dalam mendidik kemandirian anak tersebut oleh karena itu orang tua memiliki peranan yang sangat penting bagi anaknya sendiri. 
Cara Orang Tua Menanamkan Kemandirian Anak Dalam Kegiatan Pembelajaran Online Selama Masa Belajar Di Rumah

Berdasarkan hasil temuan dilapangan melalui wawancara bahwa menanamkan kemandirian pada anak dari 7 orang tua hanya 3 orang tua yang melakukan penanaman kemandirian sepenuhnya pada anak sedangkan, untuk 4 orang tua lainnya masih dalam tahap senang mengawasi apa yang dilakukan oleh anak. Selanjutnya, peneliti melakukan observasi untuk mendalami hasil wawancara yang didapat. Dari hasil observasi yang didapat terhadap 7 sampel yang ditentukan oleh peneliti, peneliti menyimpulkan bahwa cara orang tua menanamkan kemandirian anak dalam kegiatan belajar online selama masa belajar dirumah yaitu dengan memanfaatkan lingkungan sekitar untuk menanamkan kemandirian anak pada masa belajar dirumah, karena menurut 2 orang dari 7 sampel orang tua mereka mengatakan bahwa lingkungan sekitar sebagai media yang mudah untuk menanamkan kemandirian pada anak karena keseharian anak akan berhubungan langsung dengan lingkungan sekitar dimana anak akan merasa nyaman, sebab-sebab kecil yang orang tua tanamkan untuk membantu kemandirian anak yaitu dengan kegiatan kecil seperti anak mempersiapkan alat tulis dan buku secara mandiri tanpa bantuan orang tua. Maka berdasarkan fakta temuan dari hasil wawancara dan observasi penelitian tersebut hal, ini sesuai dengan apa yang dikatakan oleh Bachrudin Mustafa dalam buku (Wiyani, 2013) mengatakan bahwa "kemandirian merupakan kemampuan untuk mengambil pilihan dan menerima akibat atas perbuatan yang dilakukannya. Kemandirian pada anak akan terwujud jika mereka menggunakan pikirannya sendiri dalam mengambil berbagai keputusan, seperti dimulai dari memilih perlengkapan belajar yang ingin digunakannya, memilih teman bermain sampai hal-hal yang relatih lebih rumit disertai akibat tertentu yang lebih serius".

\section{Cara Orang Tua Menanamkan Kemandirian Anak Dalam Kegiatan Menolong Diri Sendiri} (Self Help)

Berdasarkan hasil temuan dilapangan melalui wawancara bahwa menanamkan kemandirian anak dalam kegiatan menolong diri anak (Self Help) dengan cara membiarkan anak melakukan sendiri terlebih dahulu, setelah anak berusaha melakukan sesuatu dengan sendirinya, dan hasilnya belum maksimal atau belum sesuai apa yang diharapkan dalam menyelesaikan sesuatu tersebut anak akan dengan sendirinya meminta tolong pada orang tua untuk membantu melakukannya. Kemudian, orang tua memberikan contoh, melatih, membimbing, mengajarkan serta membiasakan anak melakukan sesuatu dengan sendirinya terlebih dahulu tanpa bantuan orang tua agar anak dapat mandiri dalam menolong dirinya tersebut ketika orang tua sedang sibuk bekerja anak tidak lagi meminta bantuan orang tua. Sedangkan hasil observasi temuan dilapangan penulis menemukan beberapa kegiatan sederhana yang anak lakukan secara mandiri seperti memakai pakaian rapih secara mandiri pada saat belajar di rumah, membersihkan dan merapihkan rambut sendiri serta kegiatan Slef Help ini juga ada beberapa anak yang belum sepenuhnya mandiri dan menerapkan self help karena beberapa faktor seperti orang tua yang masih suka membantu, keterkaitannya dengan waktu karena jika anak mengerjakan sendiri orang tua merasa hal ini akan lama untuk selesai, ada juga yang karena faktor usia anak yang belum sepenuhnya bisa melakukan aktivitasnya secara mandiri. Maka berdasarkan fakta temuan dari hasil wawancara dan observasi penelitian tersebut hal, ini sesuai dengan salah satu ciri-ciri kemandirian anak menurut Hadiyanto didalam artikel (Hidayah, 2017) yaitu mengambil keputusan sendiri serta memberikan kepercayaan pada anak dan Mempunyai kecenderungan memecahkan masalah sendiri (self help) serta termasuk juga kedalam stimulasi mengembangkan keterampilan menolong diri (self help skills) Anak menurut (Azizah Muis, 2018).

\section{Hambatan Bagi Orang Tua Dalam Menanamkan Kemandirian Anak Pada Masa Belajar Di Rumah}

Berdasarkan hasil temuan dilapangan melalui wawancara bahwa dari 7 responden tersebut peneliti menyimpulkan bahwa orang tua memiliki kesibukan yang berbeda-beda dalam melakukan aktivitas sehari - hari dalam melatih atau menanamkan kemandirian pada anak misalnya orang tua harus membagi waktu antara pekerjaan dan mendidik anak walaupun kondisi saat ini sedang pandemi orang tua tidaklah sepenuhnya berperan aktif dalam mendidik 
anak. Dari 7 responden orang tua yang berprofesi sebagai sebagai guru 2 orang dan 5 orang tua lainnya sebagai ibu rumah tangga. Adapun hasil observasi tentang hambatan tentang orang tua dalam menanamkan kemandirian anak pada masa kegiatan belajar di rumah diantaranya hambatan mengenai peran orang tua dalam menanamkan kemandirian anak pasti akan mengalami berbagi hambatan dari beberapa faktor permasalahan misalnya, faktor lingkungan, karena lingkungan akan sangat berpengaruh terhadap perilaku dan katrakter yang dimiliki oleh anak dan orang tua tidak bisa sepenuhnya mengawasi setiap kegiatan yang anak lakukan pada saat berada di lingkungan sekitar misalnya pada saat mereka bermain dengan teman sebayanya atau sendiri dengan media televisi sebagai temannya, adapula anak yang senang bermain handphone untuk menemaninya bermain, internet juga menjadi salah satu masalah yang dihadapi bagi orang tua dalam meningkatkan kemandirian anak karena saat ini anak sedang berada di era digital anak - anak bisa dengan mudah mendapatkan akses internet tanpa pengawasan orang tua hal ini juga dapat berpengaruh terhadap pola kemandirian yang dimiliki anak. Maka berdasarkan fakta temuan dari hasil wawancara dan observasi penelitian tersebut hal, ini sesuai dengan pendapat Abdulrachman di dalam artikel bahwa mendampingi anak belajar di rumah, agar orang tua mengerjakan pekerjaan yang harus diselesaikan dari sekolah atau dari rumah untuk menggantikan semua peran guru disekolah yaitu orang tua yang memahami pendidikan bahwa belajar tidak hanya ketika perlu diterapkan dan dikoordinasikan antara guru dan orang tua dengan orang tua di lingkungan sekolah. Peran pengawasan menunjukan bahwa dalam keluarga, orang tua merupakan subsistem terkait interaksi orang tua dengan anak, yang didalamnya berperang untuk mengontrol, mengawasi, melindungi, membesarkan dan mendisiplinkan anak (Partiwi,, M. R,.., Mukaramah,M, \& Herdiningsih, M, Jurnal Pendidikan Pers)

\section{Kesimpulan}

Berdasarkan hasil penelitian yang telah dilakukan peneliti tentang Peran Orang Tua Dalam Meningkatkan Kemandirian Anak Pada Kegiatan Belajar Di Rumah Di TK Pgri Tunas Mekar peneliti dapat menarik kesimpulan sebagai berikut:

Orang Tua Menanamkan Kemandirian Anak Dalam Kegiatan Ibadah Harian Selama Masa Belajar Di Rumah yaitu ada beberapa cara untuk kita sebagai peran orang tua atau pengasuh dan mendidik dalam keluarga, orang tua sangat berperan penting bagi anak karena orang tua yang paling pokok dalam meletakkan dasar pendidikan ketika berperilaku, berakhlak, sikap, dan kebiasaan orang tua akan selalu diikuti oleh anak terutama di lingkungan terdekat anak seperti anak melihat orang tuannya mengaji, shalat, mengucapkan kata-kata baik atau buruk dan lain sebagainya. Berdasarkan beberapa hasil penelitian menujukan bahwa cara orang tua menanamkan kemandirian dalam kegiatan belajar onlinen selama masa belajar di rumah menujukan orang tua harus menumbuhkan motivasi, menumbuhkan sikap percaya diri dalam mengerjakan tugas dari guru, kepada anak saat anak mau belajar selama masa belajar di rumah dan membiasakan anak untuk belajar mandiri ketika memecahkan masalah dalam berpikir serta anak akan aktif dan kreatif dalam menyelesaikan tugasnya tanpa bantuan orang tua atau orang lain. Bagi Orang Tua Dalam Menanamkan Kemandirian Anak Pada Masa Belajar Di Rumah ada beberapa hambatan diantaranya yaitu: pekerjaan orang tua, menyesuaikan kondisi anak dan lingkungan, waktunya terbatas, pengalaman pendidikan orang tua dan sebagainya

\section{Acknowledge}

Penelitikan ucapan terima kasih kepada Bapak Dr. Masnipal Mahrun, M.Pd sebagai Dosen Pembimbing I yang telah bersedia membimbing secara perlahan memberikan arahan, semangat dan masukan-masukan berharga kepada peneliti sehingga dapat menyelesaikan penelitian Skripsi ini. Ibu Nurul Afrianti, S.Pd, M.Pd.,Msi.Psi selaku Pembimbing II yang penuh rasa cinta dan kasih sayang yang telah bersedia membimbing secara perlahan memberikan arahan secara penuh rasa sabar, serta semangat dan memberikan saran-saran terbaik kepada peneliti sehingga peneliti dapat menyelesaikan skripsi ini. Ibu Dr. Hj. Erhamwilda, M.Pd selaku ketua Program Studi PG-PAUD, Fakultas Tarbiyah dan Keguruan Universitas Islam Bandung. Ibu Dr. Huriah 
Rachmah, M.Pd sebagai Dosen Penguji 2 yang telah bersedia menguji saya pada saat sidang sikripsi serta memberikan saran-saran terbaik.Bapak Eko Surbiantoro, M. Pd.I sebagai Dosen Penguji 3 yang telah bersedia menguji saya pada saat sidang sikripsi serta memberikan saransaran terbaik. Bapak Arif Hakim M.Pd sebagai Dosen Penguji 4 yang telah bersedia menguji saya pada saat sidang sikripsi serta memberikan saran-saran terbaik. Ibu Dinar Nur Inten, M.Pd selaku Dosen Wali.

Seluruh Dosen PGPAUD dan Staff Administrasi, Akademik Fakultas Tarbiyah dan Keguruan Universitas Islam Bandung.

\section{Daftar Pustaka}

[1] Perkembangan Peserta Didik. Jakarta : Bumi Aksara .

[2] Azizah Muis, S. M. (2018). keterampilan menolong diri sendiri self help skills. universitas negri jakarta .

[3] Diadha , \& Reminur. (2015). Keterlibatan Orang Tua Dalam Pendidikan Anak Usia Dini Ditaman Kanak-Kanak . Ilmu Pendidikan Dan Pengajaran.

[4] Dr. Idrus Sere, M. (2018). Tanggung Jawab Orang Tua Dalam Mendidik Anak. pendidikan

[5] Erhamwilda. (2018). Psikologi Belajar Islam . Yogyakarta : Psikosain.

[6] Hidayah, B. N. (2017). Pola Asuh Orang Tua Dalam Mengembangkan Kemandirian Anak Usia Dini. pendidikan .

[7] Lilawati, A. (2020). Peran Orang Tua Dalam Mendukung Kegiatan Pembelajaran Di Rumah Pada Masa Pandemin. Jurnal Pendidikan Anak Usia Dini.

[8] Ma"mur Daud, Terjemahan Hadis Shahih Muslim, (Jakarta: Fa. Widjaya, Cet., II, 1986), hlm. 242-243.

[9] Partiwi,, M. R,.., Mukaramah,M, \& Herdiningsih, M. (Jurnal Pendidikan Pers). peran Pengawasan Orang Tua Pada Anak Penggunaan Media Sosial. 2018.

[10] Sugiyono. (2017). Metode Penelitian . Bandung : Supiah.

[11] Wiyani, N. A. (2013). Bina Karakter Anak Usia Dini . Yogyakarta. 